\title{
HYDROGEN PEROXIDE AS A SIGNAL MEDIATOR AT INDUCING HEAT RESISTANCE IN WHEAT SEEDLINGS BY PUTRESCINE
}

\author{
Yu. E. KOLUPAEV $V^{1,2}$, A. I. KOKOREV ${ }^{1}$, T. O. YASTREB ${ }^{1}$, E. I. HORIELOVA ${ }^{1}$ \\ ${ }^{1}$ Dokuchaev Kharkiv National Agrarian University, Ukraine, \\ e-mail: plant_biology@ukr.net; \\ ${ }^{2}$ Karazin Kharkiv National University, Ukraine
}

Received: 27 May 2019; Accepted: 18 October 2019

\begin{abstract}
Polyamines are multifunctional stress metabolites of plants. However, information on the effect of exogenous polyamines on plant resistance to high temperatures is contradictory, and it remains unclear which signal mediators are involved in the realization of their physiological effects. The possible involvement of hydrogen peroxide as a mediator under the action of exogenous diamine putrescine on the resistance of etiolated wheat seedlings (Triticum aestivum L.) to hyperthermia (10-minute heating at $46{ }^{\circ} \mathrm{C}$ ) and the functioning of antioxidant system was investigated. It was established that the treatment of seedlings with putrescine in 0.25-2.5 mM concentrations caused a significant increase in their heat resistance. In response to the putrescine effect, a transient increase in the $\mathrm{H}_{2} \mathrm{O}_{2}$ content occurred in the root cells. This effect was eliminated by treatment of seedlings with a diamine oxidase inhibitor aminoguanidine and an NADPH oxidase inhibitor imidazole. These inhibitors, as well as the scavenger of hydrogen peroxide dimethylthiourea (DMTU), mitigated the effects of increased heat resistance of seedlings and increased activity of superoxide dismutase and catalase caused by putrescine. Under the influence of DMTU and imidazole, but not aminoguanidine, the effect of increasing the activity of guaiacol peroxidase in the roots of seedlings treated with putrescine was eliminated. The conclusion was made about the role of hydrogen peroxide and the possible participation of diamine oxidase and NADPH oxidase in its formation during the implementation of the stress-protective effect of putrescine on wheat seedlings.
\end{abstract}

Keywords: polyamines, putrescine, hydrogen peroxide, diamine oxidase, NADPH oxidase, antioxidant enzymes, heat resistance, Triticum aestivum.

$\mathrm{P}$ olyamines are necessary components of a plant cell, able to regulate many vital processes both under physiologically normal conditions and stress ones [1-3]. An increase in the endogenous content of polyamines under the action of drought, salinity, hypo-and hyperthermia, hypoxia, ozone, ultraviolet radiation and heavy metals has been recorded [4-7].

Under stress conditions, polyamines appear to perform various functions in plant cells. Due to their cationic character at physiological $\mathrm{pH}$ values, they are able to reversibly interact with negatively charged macromolecules (proteins, phospholipid "heads" of membranes), thereby stabilizing their structure $[3,8]$. In addition to the direct impact on the biomacromolecules, polyamines, catabolizing with the formation of hydrogen peroxide and nitrogen monoxide, are involved in cellular signaling processes [3]. Among the other properties of polyamines, antioxidant are important. Many authors classify them as water-soluble compounds with antioxidant properties along with glutathione, ascorbate, polyphenols, and proline [7, 9, 10].

It is assumed that one of the components of the direct protective action of polyamines under stress conditions is the binding of radical reactive oxygen species (ROS) [11]. At the same time, polyamines can have an indirect antioxidant effect, causing an

(c) 2019 Kolupaev Yu. E. et al. This is an open-access article distributed under the terms of the Creative Commons Attribution License, which permits unrestricted use, distribution, and reproduction in any medium, provided the original author and source are credited. 
increase in gene expression and a rise in the activity of antioxidant enzymes [12]. In rice plants, an increase in the activity of catalase and glutathione reductase was detected under the influence of putrescine at salt stress [13]. Treatment of chickpea plants with putrescine, spermine and spermidine contributed to an increase in the activity of catalase and superoxide dismutase (SOD) under cold stress [14]. Stevia plants increased their catalase activity under hypothermia conditions when treated with synthetic polyamines [15]. Spraying rice plants with spermidine increased SOD, catalase, glutathione-Stransferase and ascorbate peroxidase activity after exposure to heat stress [16].

A magnification of the antioxidant enzymes activity against the background of rise in the content of polyamines in plants may be associated with the formation of a signal inducing the antioxidant system. One of the most likely mechanisms of such activation may be an increase in the content of hydrogen peroxide as a result of the oxidation reaction of polyamines by polyamine oxidase or diamine oxidase [3]. However, apparently, this is not the only mechanism for enhancing the ROS generation in plants under the influence of polyamines. Thus, there is evidence of the ability of exogenous polyamines to increase the activity of NADPH oxidase [17]. On the other hand, there is data about the inhibition of NADPH oxidase by putrescine [13].

In general, the possible role of ROS as signaling mediators in the implementation of the stressprotective effect of polyamines, as well as the contribution of individual enzymes to the change in redox homeostasis that occurs under their influence, is still little studied. This fully applies to the processes of changing heat resistance of plants under the influence of polyamines, information about which is contradictory [18]. This limits the practical use of polyamines, including the most common of them, putrescine, as a plant stress protectors.

The aim of the work was to establish a possible causal relationship between changes of redox homeostasis caused by putrescine in wheat seedlings and increasing their heat resistance. The work also included an assessment of the contribution of diamine oxidase and NADPH oxidase to the realization of the physiological effects of putrescine.

\section{Materials and Methods}

The work was carried out on etiolated seedlings of soft winter wheat (Triticum aestivum L.) var. Doskonala, grown at $22{ }^{\circ} \mathrm{C}$ on purified tap water. On the third day of seed germination, putrescine was added to the medium at concentrations of 0.05$2.5 \mathrm{mM}$ and the seedlings were kept on these solutions for one day. To clarify the involvement of ROS in the implementation of putrescine physiological effects, the antioxidant dimethylthiourea (DMTU $150 \mu \mathrm{M})$, the diamine oxidase inhibitor aminoguanidine $(1 \mathrm{mM})$ or the NADPH oxidase inhibitor imidazole $(10 \mu \mathrm{M})$ were added to the incubation medium of seedlings of the corresponding variants [19, 20]. Control samples continued to incubate on purified water. When processed together with putrescine, these compounds were introduced into the incubation medium $2 \mathrm{~h}$ before the polyamine was added to it. The maximum incubation time of seedlings on solutions of the studied compounds was 24-26 h.

To determine the heat resistance of the seedlings, they were subjected to damaging heating in a water ultrathermostat at a temperature of $46.0 \pm 0.1^{\circ} \mathrm{C}$ for $10 \mathrm{~min}$. After that, samples of all variants were transferred to purified tap water. In 3 days after exposure to damaging heating, the relative number of surviving seedlings was assessed [20].

For biochemical analyzes, the roots of intact seedlings were used, which quickly respond to exogenous compounds and are considered a convenient object for studying the mechanisms of redox homeostasis change [20, 21].

The content of hydrogen peroxide was determined by the ferrothiocyanate method, extracting it from the roots pounded in the cold 5\% TCA. The samples were centrifuged in an MPW 350R centrifuge (MPW MedInstruments, Poland) at $8000 \mathrm{~g}$ for $10 \mathrm{~min}$ at a temperature not exceeding $4{ }^{\circ} \mathrm{C}$, and the $\mathrm{H}_{2} \mathrm{O}_{2}$ concentration was determined in the supernatant [22].

The activity of antioxidant enzymes was determined by the methods described in detail earlier $[20,23]$. Weights of the roots were homogenized at $2-4^{\circ} \mathrm{C}$ in $0.15 \mathrm{M} \mathrm{K}$, Na-phosphate buffer ( $\mathrm{pH}$ 7.6) with the addition of EDTA $(0.1 \mathrm{mM})$, dithiothreitol $(1 \mathrm{mM})$, and detergent Triton X-100 (final concentration $0.1 \%$ ). For the analysis, the supernatant was used after centrifuging the homogenate at $8000 \mathrm{~g}$ for 10 min at $4{ }^{\circ} \mathrm{C}$.

Total SOD activity (EC 1.15.1.1) was determined at the reaction mixture $\mathrm{pH}$ 7.6, using a method based on the ability of the enzyme to compete with nitroblue tetrazolium for superoxide anions formed as a result of the aerobic interaction of 
NADH and phenazine methosulfate. Catalase activity (EC 1.11.1.6) was analyzed at $\mathrm{pH} 7.0$ by the amount of $\mathrm{H}_{2} \mathrm{O}_{2}$ that decomposed per unit of time. The activity of guaiacol peroxidase (EC 1.11.1.7) was determined using guaiacol as a hydrogen donor and hydrogen peroxide as a substrate. Using a K,Naphosphate buffer, the $\mathrm{pH}$ of the reaction mixture was adjusted to 6.2 .

Measurements were performed in at least three biological and three analytical replicates. The mean values and standard errors are given. The significance of the differences was evaluated by Student's $t$-test. Except as otherwise specified, differences that are significant at $P \leq 0.05$ are discussed.

\section{Results and Discussion}

Treatment of wheat seedlings with putrescine in concentrations of $0.25-2.5 \mathrm{mM}$ caused a noticeable increase in their resistance to damaging heating (Fig. 1). The maximum effect was observed with $1 \mathrm{mM}$ putrescine. In this regard, precisely this concentration of polyamine was used in subsequent experiments.

Treatment of the roots of intact seedlings with $1 \mathrm{mM}$ putrescine led to a transient increase in hydrogen peroxide content in them (Fig. 2). The maximum was observed $2 \mathrm{~h}$ after the putrescine exposure start. By the end of the incubation (24 h), the $\mathrm{H}_{2} \mathrm{O}_{2}$ content only slightly exceeded the corresponding value in the control.

As noted, the effect of elevating the content of hydrogen peroxide under the action of polyamines

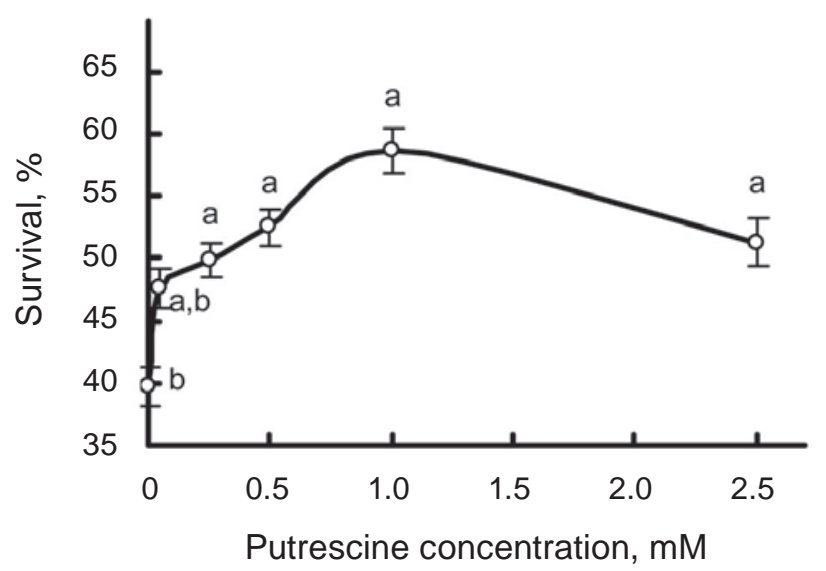

Fig. 1. Concentration dependence of the putrescine influence on the resistance of wheat seedlings to damaging heating $\left(10 \mathrm{~min}\right.$ at $\left.46^{\circ} \mathrm{C}\right)$. Values followed by the same letter are not significantly different $(P \leq 0.05)$. may be due to an increase in the activity of polyamine oxidases and/or NADPH oxidase. To determine the contribution of these enzymes to the putrescineinduced accumulation of hydrogen peroxide, seedlings before exposure to putrescine were incubated in a medium supplemented with aminoguanidine, a diamine oxidase inhibitor, or imidazole, a NADPH oxidase inhibitor. It turned out that aminoguanidine itself did not affect the $\mathrm{H}_{2} \mathrm{O}_{2}$ content in the roots of seedlings (Fig. 3). At the same time, it completely eliminated the effect of the accumulation of hydrogen peroxide caused by putrescine. Treatment of seedlings with imidazole caused a tendency to a decrease in the hydrogen peroxide content in the roots. At the combined action of imidazole and putrescine, the effect of the latter was largely leveled out (Fig. 3). The amount of hydrogen peroxide in the roots was reduced under the influence of an antioxidant DMTU. At the same time, the $\mathrm{H}_{2} \mathrm{O}_{2}$ scavenger completely removed the effect of increasing the hydrogen peroxide content under the action of putrescine (Fig. 3).

The seedlings' treatment with DMTU, aminoguanidine and imidazole did not have a significant effect on their heat resistance (Fig. 4). At the combined treatment of seedlings, scavenger of hydrogen peroxide and inhibitors of diamine oxidase and NADPH oxidase completely eliminated the positive effect of putrescine on the resistance of seedlings to heating.

There are reasons to believe that hydrogen peroxide, formed during the treatment of seedlings with

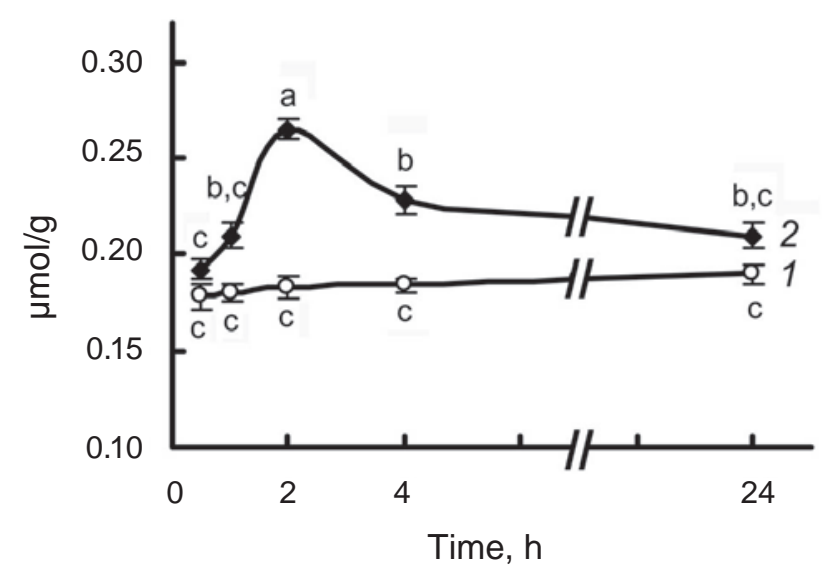

Fig. 2. Dynamics of the hydrogen peroxide content $(\mu \mathrm{mol} / \mathrm{g})$ in the roots of wheat seedlings under the action of putrescine. 1 - Control; 2 - putrescine $(1 \mathrm{mM})$. Values followed by the same letter are not significantly different $(P \leq 0.05)$ 


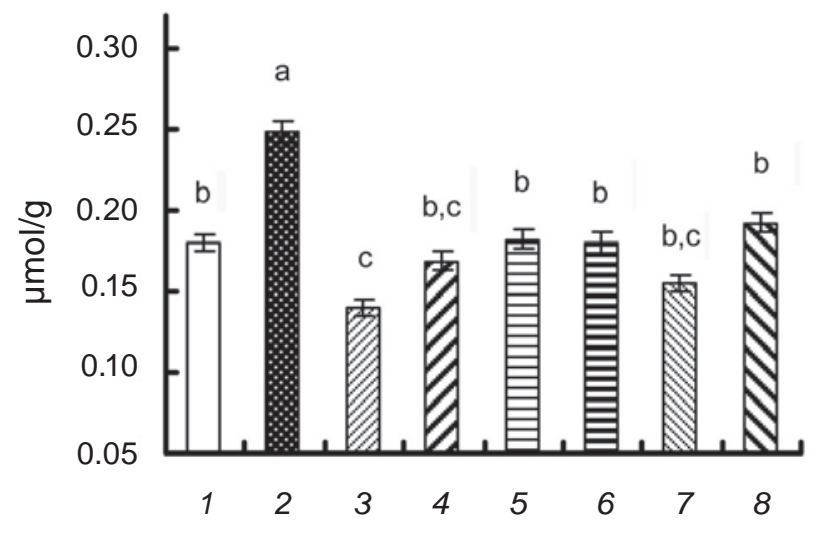

Fig. 3. The content of hydrogen peroxide ( $\mu \mathrm{mol} / \mathrm{g})$ in the roots of wheat seedlings under the action of putrescine, DMTU, aminoguanidine and imidazole. 1 - Control; 2 - putrescine (1 mM); 3 - DMTU (150 $\mu M) ; 4$-putrescine $(1 \mathrm{mM})+\mathrm{DMTU}(150 \mu \mathrm{M})$; 5 - aminoguanidine (1 mM); 6 - putrescine (1 mM) + aminoguanidine (1 mM); 7 - imidazole $(10 \mu M)$; 8 - putrescine $(1 \mathrm{mM})+$ imidazole $(10 \mu \mathrm{M})$. The roots putrescine treatment was carried out for $2 h$, DMTU and enzyme inhibitors were added to the incubation medium of roots $2 \mathrm{~h}$ before adding of putrescine. Values followed by the same letter are not significantly different $(P \leq 0.05)$

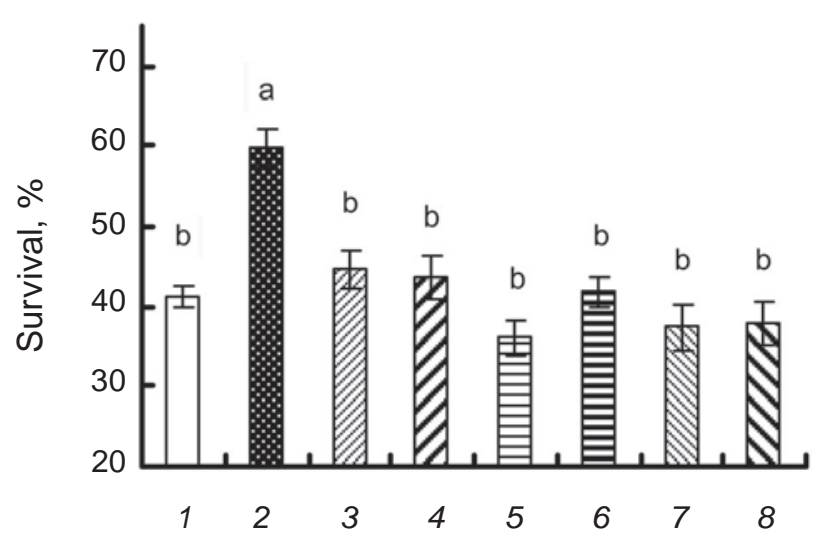

Fig. 4. Survival of seedlings (\%) after damaging heating $\left(10 \mathrm{~min}\right.$ at $\left.46{ }^{\circ} \mathrm{C}\right)$ after treatment with putrescine, DMTU, aminoguanidine and imidazole. 1 - Control; 2 - putrescine (1 mM); 3 - DMTU $(150 \mu M) ; 4$ - putrescine $(1 \mathrm{mM})+D M T U(150 \mu M)$; 5 - aminoguanidine (1 mM); 6 - putrescine (1 mM) + aminoguanidine (1 mM); 7 - imidazole $(10 \mu M)$; 8 -putrescine $(1 \mathrm{mM})+$ imidazole $(10 \mu \mathrm{M})$. Values followed by the same letter are not significantly different $(P \leq 0.05)$
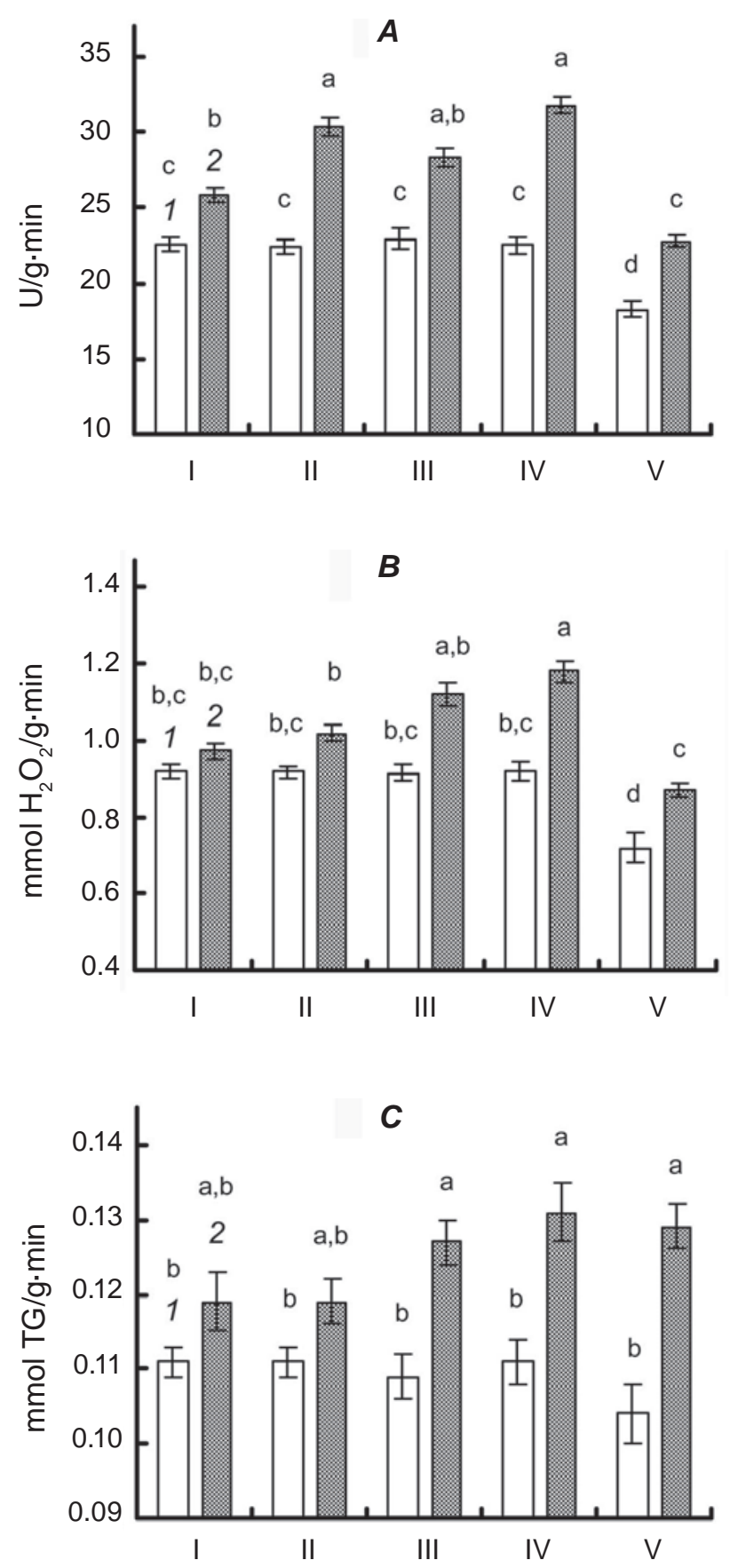

Fig. 5. Dynamics of activity of SOD (U/g.min) (A), catalase (mmol $\left.\mathrm{H}_{2} \mathrm{O}_{2} / \mathrm{g} \cdot \mathrm{min}\right)$ (B) and guaiacol peroxidase (mmol tetra guaiacol (TG)/g.min) (C) in the roots of wheat seedlings under the action of putrescine and damaging heating. I-IV - respectively: 1 , 2, 4 and $24 \mathrm{~h}$ after the start of treatment with putrescine, $V-4$ h after warming up at $46^{\circ} \mathrm{C} .1$ - control; 2 - putrescine $(1 \mathrm{mM})$. Values followed by the same letter are not significantly different $(P \leq 0.05)$ 
putrescine, acts as a signal for inducing protective systems involved in resistance to hyperthermia. It is logical to assume that one of these systems is antioxidant. In our experiments, putrescine treatment of seedlings caused an increase in the total SOD activity in the roots; the maximum effect was observed $24 \mathrm{~h}$ after the start of treatment (Fig. 5, A). In $4 \mathrm{~h}$ after damaging heating, the enzyme activity in roots of the seedlings of the control and experimental variants decreased, however, the absolute values of SOD activity in the variant with putrescine remained higher.

When treated with putrescine, catalase activity in the roots also increased (Fig. 5, B). The most conspicuous effects were noted after 4 and $24 \mathrm{~h}$ of its action. After heating, the activity of catalase in the roots of seedlings of both variants, as well as the activity of SOD, decreased. However, the absolute values of catalase activity in the putrescine variant were significantly higher than in the control.

The activity of guaiacol peroxidase in the roots in 4 and $24 \mathrm{~h}$ after the onset of exposure to putrescine increased slightly but significantly at $P \leq 0.05$ (Fig. 5, C). After damaging heating, the activity of the enzyme in the roots did not change significantly, wherein the values in the putrescine variant remained higher than in the control.

If we assume that ROS are mediators in the process of inducing enzyme antioxidant system by putrescine, its effect on the activity of enzymes should depend on the content of ROS. To test this hypothesis, we studied the impact of DMTU, aminoguanidine and imidazole on the activity of antioxidant enzymes in the roots of seedlings during their treatment with putrescine. The hydrogen peroxide scavenger DMTU itself did not significantly affect the activity of SOD and catalase, but caused a slight decrease in the guaiacol peroxidase activity in the roots (Fig. 6). At the same time, it completely leveled off the effects of increasing the activity of all three antioxidant enzymes caused by the action of putrescine.

When seedlings were treated with aminoguanidine, the diamine oxidase inhibitor, SOD activity did not change significantly, catalase activity decreased, and guaiacol peroxidase activity, on the contrary, increased (Fig. 6). At the same time, aminoguanidine leveled the effect of elevating SOD and catalase activity by putrescine. At the same time, the activity of guaiacol peroxidase in the variant with the combination of aminoguanidine and putrescine was
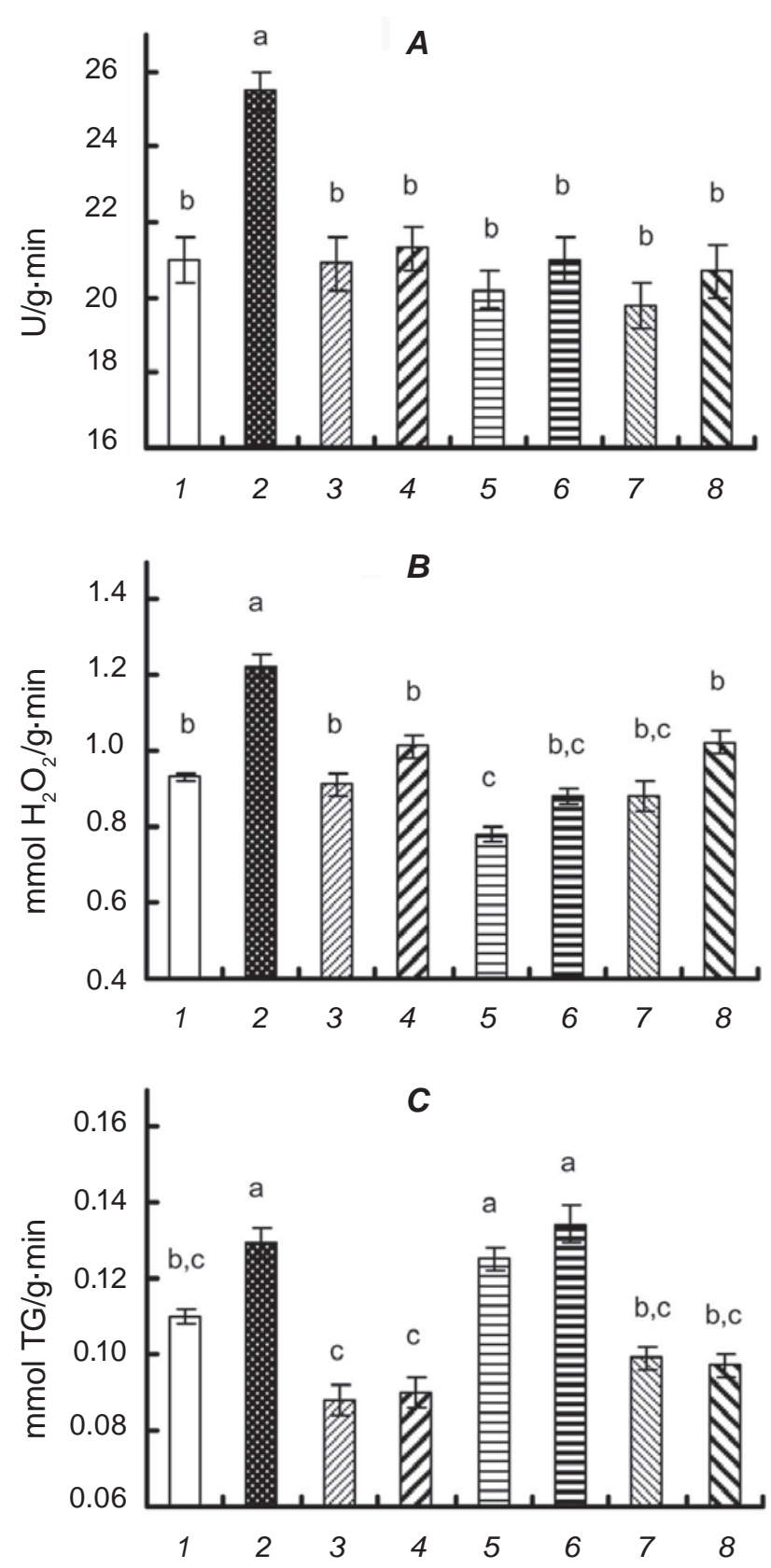

Fig. 6. Activity of SOD (U/g.min) (A), catalase ( $\mathrm{mmol}$ $\left.\mathrm{H}_{2} \mathrm{O}_{2} / \mathrm{g} \cdot \mathrm{min}\right)$ (B) and guaiacol peroxidase (mmol tetra guaiacol $(T G) / g \cdot m i n)(C)$ in the roots of wheat seedlings under the action of putrescine, DMTU, aminoguanidine and imidazole. 1 - control; 2 - putrescine (1 $\mathrm{mM}) ; 3$-DMTU (150 $\mu \mathrm{M}) ; 4$-putrescine (1 mM) + DMTU $(150 \mu M) ; 5$ - aminoguanidine (1 mM); 6 - putrescine $(1 \mathrm{mM})+$ aminoguanidine $(1 \mathrm{mM})$; 7 -imidazole $(10 \mu M) ; 8$-putrescine $(1 \mathrm{mM})+$ imidazole $(10 \mu \mathrm{M})$. The roots putrescine treatment was carried out for 24 h, DMTU and enzyme inhibitors were added to the incubation medium of roots $2 \mathrm{~h}$ before adding of putrescine. Values followed by the same letter are not significantly different $(P \leq 0.05)$ 
higher than in the control; its absolute values were approximately the same as at the treatment with aminoguanidine or putrescine alone.

The treatment of seedlings with imidazole did not cause significant changes in the activity of all three studied antioxidant enzymes (Fig. 6). At the same time, the NADPH oxidase inhibitor eliminated the rise in SOD, catalase and guaiacol peroxidase activity caused by putrescine.

Thus, in general, the results obtained indicate the involvement of hydrogen peroxide as a signal mediator in the process of the antioxidant system activation and heat resistance induction in wheat seedlings under the influence of putrescine. Activation of the enzymatic component of the antioxidant system is one of the key mechanisms in plant adaptation to hyperthermia and drought [24-26]. It is noteworthy that the activation of all three studied enzymes occurred 4-24 $\mathrm{h}$ after the start of treatment with putrescine (Fig. 5), that is after the maximum increase in the hydrogen peroxide content, which was observed $2 \mathrm{~h}$ after the start of treatment (Fig. 2). Not only the dynamics of these processes but also the results of the inhibitory analysis indicate a causal relationship between the formation of hydrogen peroxide and the increased activity of antioxidant enzymes under the influence of putrescine. The positive effect of putrescine was completely eliminated by the $\mathrm{H}_{2} \mathrm{O}_{2}$ scavenger DMTU, which removed the transient effect of elevating hydrogen peroxide content in the roots (Fig. 3), the increase in SOD, catalase and guaiacol peroxidase activity (Fig. 6), and the development of heat resistance (Fig. 5).

It can be assumed that at least one of the reasons for the enhancing hydrogen peroxide content in the roots under the influence of putrescine was activation of diamine oxidase, an enzyme of its catabolism leading to the $\mathrm{H}_{2} \mathrm{O}_{2}$ formation. This is indicated by the elimination of the hydrogen peroxide accumulation in the variant with putrescine treatment in the presence of aminoguanidine (Fig. 3). On the other hand, an increase in the content of hydrogen peroxide caused by putrescine was also largely suppressed by the inhibitor of NADPH oxidase, imidazole. The participation of at least these two enzymes in the formation of hydrogen peroxide under the action of putrescine was indicated by the results obtained on soybean plants [10]. The authors believe that diamine oxidase and polyamine oxidase together with NADPH oxidase provide the cell walls suberization effect caused by polyamines. In Arabidopsis plants, an increase in the NADPH oxidase activity was observed under the influence of exogenous spermidine [17]. On the other hand, in cucumber plants, exogenous spermidine eliminated the effects of enhancing activity of NADPH oxidase and content of hydrogen peroxide caused by the action of low positive temperatures [27]. At the same time, under normal temperature conditions, spermidine did not significantly affect the activity of the enzyme. Probably, the effect of polyamines on the NADPH oxidase activity in vivo depends on many factors and may be partly due to their participation in membrane stabilization. Nevertheless, there is a reason to believe that, in our experimental conditions, the formation of the "signaling pool" of ROS, necessary for the realization of the putrescine effects, occurs with the participation of NADPH oxidase. It is noteworthy that NADPH oxidase in the plasma membrane can be activated by ROS themselves, initially formed in other cellular compartments or on the surface of neighboring cells [28]. It is assumed that an increase in ROS content, which occurs stochastically under action of stressors, or with the participation of other enzymes, can turn into a more powerful signal associated with the activation of NADPH oxidase [28, 29]. It is not excluded that the stimulus for the activation of NADPH oxidase under the action of exogenous putrescine may be the formation of hydrogen peroxide associated with its catabolism with the participation of diamine oxidase.

The diamine oxidase inhibitor aminoguanidine in our experiments eliminated putrescine-induced effects of elevating the hydrogen peroxide content in the roots, increasing SOD and catalase activity, and the development of heat resistance of seedlings. Partly similar effects have been reported when studying the action of another diamine, cadaverine, on Mesembryanthemum crystallinum L. plants. An increase in hydrogen peroxide and catalase activity in roots, caused by cadaverine, was suppressed by aminoguanidine [19]. On the other hand, on plants of the same species, it was shown that the effect of enhancing expression of the gene encoding the cytoplasmic isoform $\mathrm{Cu} / \mathrm{Zn}$-SOD caused by cadaverine was not eliminated by diamine oxidase inhibitors, on the basis of which the authors suggested the possibility of direct influence of polyamine on gene expression [12]. Thus, one cannot exclude the presence of several different influence mechanisms of polyamines on the activity of antioxidant enzymes in plants. 
In our experiments, a difficult to explain the effect of increase the guaiacol peroxidase activity in wheat seedlings under the influence of aminoguanidine was found (Fig. 6, $C$ ). At the same time, aminoguanidine did not affect the magnitude of the putrescine-caused activating effect on the enzyme. In [19], performed on M. crystallinum plants, aminoguanidine partially eliminated the effect of increased activity of guaiacol peroxidase caused by cadaverine. However, in the tissues culture of poplar shoots, a slight increase in the activity of this enzyme was shown when introducing aminoguanidine into the medium [30].

Interpretation of the results with aminoguanidine as a diamine oxidase inhibitor is complicated by the fact that this compound also inhibits an enzyme similar to animal NO-synthase, which may be involved in the formation of nitric oxide in plants [31, 32]. Moreover, polyamines in catabolic transformations involving diamine oxidase and polyamine oxidase can act as sources of not only hydrogen peroxide, but also nitric oxide [3, 7]. In addition, the NO-synthase inhibitor L-NAME ( $\mathrm{N}^{\mathrm{G}}$-nitro-Larginine methyl ester), which is widely used in experimental practice, can inhibit not only the target enzyme but also polyamine oxidase [33]. Either way, aminoguanidine and L-NAME can inhibit catabolism of polyamines, affecting the formation of ROS and nitric oxide - signal mediators that interact with each other and have a strong influence on the activity and genes expression of antioxidant enzymes [7, 34]. It is noteworthy that the treatment with LNAME, like the impact of aminoguanidine (Fig. 6, $C$ ), caused an increase in the activity of guaiacol peroxidase in the roots of wheat seedlings [23]. It is known that nitric oxide, when it enters into the reactions of protein nitrosylation and nitration, can have a very complex both activating and inhibiting effect on the activity of antioxidant enzymes [35]. It is possible that activation of peroxidase by aminoguanidine and L-NAME is associated with changes in NO-homeostasis. However, the discussion of these effects goes far beyond the scope of this article.

In general, on the basis of the obtained results, it can be concluded that the induction of heat resistance of wheat seedlings by exogenous putrescine is associated with the formation of ROS, which occurs with the participation of diamine oxidase and NADPH oxidase, and subsequent activation of antioxidant enzymes. It is quite likely that nitric oxide, which can be formed during the catabolism of poly- amines and is functionally closely related to ROS, is also involved in the implementation of the effect of putrescine. Its participation in the putrescine protective effect under heat stress requires experimental verification.

Conflict of interest. Authors have completed the Unified Conflicts of Interest form at http://ukrbiochemjournal.org/wp-content/uploads/2018/12/ coi_disclosure.pdf and declare no conflict of interest.

\section{ГІДРОГЕН ПЕРОКСИД ЯК СИГНАЛЬНИЙ ПОСЕРЕДНИК ЗА ІНДУКУВАННЯ ТЕПЛОСТІЙКОСТІ ПРОРОСТКІВ ПШЕНИЦІ ПУТРЕСЦИНОМ}

\author{
Ю. С. Колупаєв ${ }^{1,2}$, О. I. Кокорев ${ }^{1}$, \\ T. О. Ястреб ${ }^{1}$, О. I. Горєлова ${ }^{1}$

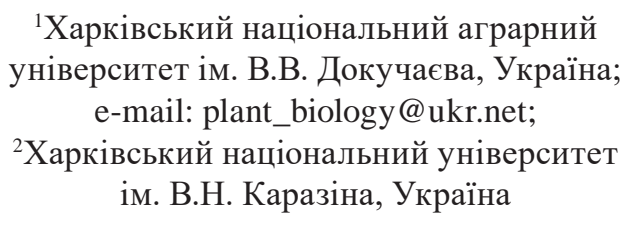

Поліаміни належать до мультифункціональних стресових метаболітів рослин. Однак відомості про вплив екзогенних поліамінів на стійкість рослин до високих температур суперечливі, при цьому залишається неясним, які сигнальні посередники задіяні в реалізації ïx фізіологічних ефектів. Досліджували можливу участь гідроген пероксиду як посередника за дії екзогенного діаміну путресцину на стійкість етіольованих проростків пшениці (Triticum aestivum L.) до гіпертермії (10-хвилинного прогрівання при $\left.46{ }^{\circ} \mathrm{C}\right)$ і функціонування антиоксидантної системи. Встановлено, що обробка проростків путресцином в концентраціях 0,25-2,5 мМ спричиняла істотне підвищення їх теплостійкості. У відповідь на дію путресцину в клітинах коренів відбувалося транзиторне збільшення вмісту $\mathrm{H}_{2} \mathrm{O}_{2}$. Такий ефект усувався обробкою проростків інгібітором діаміноксидази аміногуанідином та інгібітором NADPHоксидази імідазолом. Ці інгібітори, а також скавенджер гідроген пероксиду диметилтіосечовина (ДМТС), нівелювали спричинювані путресцином ефекти підвищення теплостійкості проростків та збільшення активності супероксиддисмутази і каталази. Під впливом ДМТС 
та імідазолу, але не аміногуанідину, усувався ефект підвищення активності гваяколпероксидази в коренях проростків, оброблених путресцином. Зроблено висновок про роль гідроген пероксиду та можливу участь діаміноксидази і NADPH-оксидази в його утворенні за реалізації стрес-протекторної дії путресцину на проростки пшениці.

К л ю ч о в і с л о в а: поліаміни, путресцин, гідроген пероксид, діаміноксидаза, NADPHоксидаза, антиоксидантні ензими, теплостійкість, Triticum aestivum.

\section{References}

1. Kusano T, Berberich T, Tateda C, Takahashi Y. Polyamines: essential factors for growth and survival. Planta. 2008; 228(3): 367-381.

2. Takahashi T, Kakehi J. Polyamines: ubiquitous polycations with unique roles in growth and stress responses. Ann Bot. 2010; 105(1): 1-6.

3. Pál M, Szalai G, Janda T. Speculation: Polyamines are important in abiotic stress signaling. Plant Sci. 2015; 237: 16-23.

4. Szalai G, Pap M, Janda T. Light-induced frost tolerance differs in winter and spring wheat plants. J Plant Physiol. 2009; 166(16): 1826-1831.

5. Alcázar R, Altabella T, Marco F, Bortolotti C, Reymond M, Koncz C, Carrasco P, Tiburcio AF. Polyamines: molecules with regulatory functions in plant abiotic stress tolerance. Planta. 2010; 231(6): 1237-1249.

6. Gill SS, Tuteja N. Polyamines and abiotic stress tolerance in plants. Plant Signal Behav. 2010; 5(1): 26-33.

7. Saha J, Brauer EK, Sengupta A, Popescu SC, Gupta K, Gupta B. Polyamines as redox homeostasis regulators during salt stress in plants. Front Environ Sci. 2015; 3: 21.

8. Pang XM, Zhang ZY, Wen XP, Ban Y, Moriguchi T. Polyamines, all-purpose players in response to environment stresses in plants. Plant Stress. 2007; 1(2): 173-188.

9. Ozgur R, Uzilday B, Sekmen AH, Turkan I. Reactive oxygen species regulation and antioxidant defence in halophytes. Funct Plant Biol. 2013; 40(9): 832-847.

10. Todorova D, Katerova Z, Sergiev I, Alexieva V. Role of polyamines in alleviating salt stress. Ecophysiology and Responses of Plants under Salt Stress. Eds. Ahmad P, Azooz MM,
Prasad MNV. New York: Springer, 2013. Vol. 13: 355-379.

11. Wimalasekera R, Tebartz F, Scherer GF. Polyamines, polyamine oxidases and nitric oxide in development, abiotic and biotic stresses. Plant Sci. 2011; 181(5) 593-603.

12. Aronova EE, Shevyakova NI, Stetsenko LA, Kuznetsov VV. Cadaverine-induced induction of superoxide dismutase gene expression in Mesembryanthemum crystallinum L. Dokl Biol Sci. 2005; 403(1-6): 257-259.

13. Ghosh N, Das SP, Mandal C, Gupta S, Das K, Dey N, Adak MK. Variations of antioxidative responses in two rice cultivars with polyamine treatment under salinity stress. Physiol Mol Biol Plants. 2012; 18(4): 301-313.

14. Nayyar H, Chander S. Protective effects of polyamines against oxidative stress induced by water and cold stress in chickpea. J Agron Crop Sci. 2004; 190(5): 355-365.

15. Peynevandi KM, Razavi SM, Zahri S. The ameliorating effects of polyamine supplement on physiological and biochemical parameters of Stevia rebaudiana Bertoni under cold stress. Plant Production Sci. 2018; 21(2): 123-131.

16. Mostofa MG, Yoshida N, Fujita M. Spermidine pretreatment enhances heat tolerance in rice seedlings through modulating antioxidative and glyoxalase systems. Plant Growth Regul. 2014; 73(1): 31-44.

17. Andronis EA, Moschou PN, Toumi I, RoubelakisAngelakis KA. Peroxisomal polyamine oxidase and NADPH-oxidase cross-talk for ROS homeostasis which affects respiration rate in Arabidopsis thaliana. Front Plant Sci. 2014; 5: 132.

18. Sagor GH, Berberich T, Takahashi Y, Niitsu M, Kusano T. The polyamine spermine protects Arabidopsis from heat stress-induced damage by increasing expression of heat shock-related genes. Transgenic Res. 2013;22(3):595-605.

19. Shevyakova NI, Rakitin VYu, Stetsenko LA, Aronova EE, Kuznetsov VV. Oxidative stress and fluctuations of free and conjugated polyamines in the halophyte Mesembryanthemum crystallinum L. under $\mathrm{NaCl}$ salinity. Plant Growth Regul. 2006; 50(1): 69-78.

20. Kolupaev YuE, Oboznyi OI. Participation of the active oxygen forms in the induction of ascorbate peroxidase and guaiacol peroxidase under heat hardening of wheat seedlings. Ukr Biokhim Zhurn. 2012; 84(6):131-138.(In Russian). 
21. Chasov AV, Minibayeva FV. Methodological approaches for studying apoplastic redox activity: 1 . Mechanisms of peroxidase release. Russ J Plant Physiol. 2014; 61(4): 556-563.

22. Sagisaka S. The Occurrence of Peroxide in a Perennial Plant, Populus gelrica. Plant Physiol. 1976;57(2): 308-309.

23. Karpets YuV, Kolupaev YuE, Yastreb TO, Oboznyi AI. Effects of NO-status modification, heat hardening, and hydrogen peroxide on the activity of antioxidant enzymes in wheat seedlings. Russ J Plant Physiol. 2015; 62(3): 292298.

24. Kiriziy DA, Shadchina TM, Stasik OO, Priadkina HO, Sokolovska-Serhiienko $\mathrm{OH}$, Huliaiev BI, Sytnyk SK. Peculiarities of photosynthesis and production process in high intensity genotypes of winter wheat. Kyiv: Osnova, 2011. 416 p. (In Ukrainian).

25. Hasanuzzaman $\mathrm{M}$, Nahar $\mathrm{K}$, Alam MM, Roychowdhury R, Fujita M. Physiological, biochemical, and molecular mechanisms of heat stress tolerance in plants. Int J Mol Sci. 2013; 14(5): 9643-9684.

26. Li B, Gao K, Ren H, Tang W. Molecular mechanisms governing plant responses to high temperatures. J Integr Plant Biol. 2018; 60(9): 757-779.

27. Shen W, Nada K, Tachibana S. Involvement of polyamines in the chilling tolerance of cucumber cultivars. Plant Physiol. 2000; 124(1): 431-439.

28. Mittler R, Vanderauwera S, Suzuki N, Miller G, Tognetti VB, Vandepoele K, Gollery M, Shulaev V, Van Breusegem F. ROS signaling: the new wave? Trends Plant Sci. 2011; 16(6): 300-309.
29. Kolupaev YuE, Karpets YuV. Reactive oxygen species and stress signaling in plants. $U k r$ Biochem J. 2014; 86(4): 18-35. (In Russian).

30. Hausman JF, Kevers C, Gaspari T. Putrescine control of peroxidase activity in the inductive phase of rooting in poplar shoots in vitro, and the adversary effect of spermidine. J Plant Physiol. 1995; 146(5-6): 681-685.

31. Corpas FJ, Barroso JB, Carreras A, Valderrama R, Palma JM, León AM, Sandalio LM, del Río LA. Constitutive arginine-dependent nitric oxide synthase activity in different organs of pea seedlings during plant development. Planta. 2006; 224(2): 246-254.

32. Glyan'ko AK. Initiation of nitric oxide (NO) synthesis in roots of etiolated seedlings of pea (Pisum sativum L.) under the influence of nitrogen-containing compounds. Biochemistry (Mosc). 2013; 78(5): 471-476.

33. Flores T, Todd CD, Tovar-Mendez A, Dhanoa PK, Correa-Aragunde N, Hoyos ME, Brownfield DM, Mullen RT, Lamattina L, Polacco JC. Arginase-negative mutants of Arabidopsis exhibit increased nitric oxide signaling in root development. Plant Physiol. 2008; 147(4): 1936-1946.

34. Kolupaev YuE, Karpets YuV, Dmitriev AP. Signal mediators in plants in response to abiotic stress: calcium, reactive oxygen and nitrogen species. Cytol Genet. 2015; 49(5): 338-348.

35. Arora D, Jain P, Singh N, Kaur H, Bhatla SC. Mechanisms of nitric oxide crosstalk with reactive oxygen species scavenging enzymes during abiotic stress tolerance in plants. Free Radic Res. 2016; 50(3): 291-303. 